\title{
Pendampingan Bimbingan Belajar Bahasa Inggris dan Bakti Sosial di Yayasan Pendidikan dan Sosial Roudlotut Thullab
}

\author{
Eka Agustina1, Ainur Rohmah², Hastuti Retno Kuspiyah ${ }^{3}$ \\ ${ }^{1}$ STKIP Nurul Huda Sukaraja \\ ${ }^{2}$ STKIP Nurul Huda Sukaraja \\ ${ }^{3}$ STKIP Nurul Huda Sukaraja \\ E-mail: ${ }^{1}$ ekaagustina@stkipnurulhuda.ac.id, ${ }^{2}$ ainur@stkipnurulhuda.ac.id, ${ }^{3}$ retno@stkipnurulhuda.ac.id
}

ABSTRAK

Available online

URL:

https://journal.stkipnurulhuda.ac.id/ index.php/JIMi/article/view/415

How to cite (APA):

Agustina, E., Rohmah, A., \&

Kuspiyah, H. (2019).

Pendampingan Bimbingan

Belajar Bahasa Inggris dan

Bakti Sosial di Yayasan

Pendidikan dan Sosial

Roudlotut Thullab. Jurnal

Indonesia Mengabdi, 1(1), 1-5.

This work is licensed under a Creative Commons

Attribution 4.0 International License

\begin{abstract}
Abstrak
Pengabdian masyarakat ini bermula dari keresahan para dosen prodi Pendidikan Bahasa Inggris akan pentingnya kebermanfaatan ilmu yang dimiliki oleh para dosen guna pendidikan masyarakat yang lebih baik diluar aktifitas pendidikan di dalam kampus. Yayasan pendidikan dan sosial Raudhatul Thullab kurang akan tenaga pendidik khususnya guru Bahasa Inggris sementara minat siswa yang cukup tinggi untuk mampu berbahasa inggris. Objek/sasaran pengabdian ini adalah siswa/santri SMP dan SMK Raudhatul Thullab, dalam melaksanakan pengabdian ini yaitu dengan model pendampingan belajar yang dilakukan selama 1 bulan. Materi bimbel meliputi grammar, reading, speaking, pronounciation dan writing. Hasil kegiatan pengabdian pada masyarakat ini mendapat sambutan positif dari pihak sekolah, terutama karena pelatihan ini sesuai dengan kebutuhan mereka. Motivasi peserta pelatihan cukup antusias. Hal ini menandakan adanya keinginan untuk meningkatkan kemampuan mereka dalam penguasaan Bahasa Inggris.
\end{abstract}

Kata kunci: Bimbingan Belajar, Bahasa Inggris

\begin{abstract}
This community service stems from the anxiety of the English Education Study Program lecturers on the importance of the usefulness of the knowledge possessed by lecturers for better community education outside of educational activities on campus. Raudhatul Thullab's educational and social foundation lacks teaching staff, especially English teachers, while students who are high enough to speak English. The object / target of this service is Raudhatul Thullab Middle School and Vocational High School students, in carrying out this service that is with a learning assistance model that is conducted for 1 month. The material includes grammar, reading, speaking, pronunciation and writing. The results of community service activities received a positive response from the school, especially because this training was suitable for their needs. The motivation of the trainees was quite enthusiastic. This indicates a desire to improve their abilities in mastering English.

Keywords: Tutoring, English
\end{abstract}

\section{PENDAHULUAN}

Pesantren dan pendidikan merupakan satu dan lain hal yang saling terkait satu sama lain. Hal ini dapat dilihat dari beberapa hal yang melatarbelakanginya sebagai lembaga syiar agama Islam yang memegang kendali paling penting dalam tatanan masyarakat dan hubungan dalam kehidupan manusia. Pondok pesantren memiliki tujuan ganda. Pertama, sebagai institusi yang harus 
mempertahankan nilai-nilai keislaman dengan menitik beratkan pada aspek pendidikan. Kedua, pondok pesantren memiliki peran dan fungsi terhadap peningkatan pendidikan masyarakat sebagai upaya meningkatkan kualitas sumber daya manusia guna membentuk masyarakat yang berperilaku dan paham akan nilai-nilai Islam.

Pesantren sebagai lembaga pendidikan Islam mengalami perkembangan bentuk sesuai dengan perubahan zaman serta adanya dampak kemajuan ilmu pengetahuan dan tekhnologi. Akan tetapi, pondok pesantren tetap merupakan lembaga pendidikan agama Islam yang tumbuh dan berkembang dari masyarakat untuk masyarakat. Pesantren adalah lembaga yang dapat dikatakan merupakan wujud proses perkembangan sistem pendidikan Islam yang juga memerlukan inovasi dalam pendidikan, bukan hanya pendidikan bagi santri di dalammnya akan tetapi juga pendidikan masyarakat di sekitarnya yang berbentuk kegiatan-kegiatan yang banyak mengkaji keagamaan.

Pesantren mempunyai fungsi pengembangan, penyebaran dan pemeliharaan kemurnian dan kelestarian ajaran-ajaran Islam dan bertujuan mencetak manusia pengabdi Allah yang ahli agama dan berwawasan luas sehingga mampu menghadapi segala masalah yang berkembang di masyarakat. Sejarah sudah mencatat bahwa pondok pesantren adalah lembga pendidikan keagamaan dan kemasyarakatan yang sudah sejak lama dikenal sebagai wahana pengembangan masyarakat.

Yayasan Pendidikan dan Sosial Roudlotut Thullab OKU Timur merupakan salah satu lembaga pendidik islam yang baru di kabupaten Ogan Komering Ulu Timur, Sumatera Selatan. Ada dua lembaga pendidikan didalamnya yaitu SMP dan SMK Roudlotut Thullab. Yayasan pendidikan ini memiliki santri-santri yang luar biasa karena hampir $80 \%$ adalah anak yatim, piatu ataupun yatim piatu. Lembaga ini selalu ingin mengikuti perkembangan zaman dan melakukan adaptasi dan akselerasi.

Pengabdian masyarakat ini bermula dari keresahan para Dosen Prodi Pendidikan Bahasa Inggris akan pentingnya kebermanfaatan ilmu yang dimiliki oleh para dosen guna pendidikan masyarakat yang lebih baik diluar aktifitas pendidikan di dalam kampus. Tergerak dan tertarik tentang hal tersebut, para dosen membahasnya dalam rapat rutin bulanan prodi. Setelah di bahas bersama, maka menghasilkan keputusan untuk melakukan kegiatan pengabdian masyarakat dan bakti sosial. Permasalahan yang ditemukan yaitu 1) keresahan para dosen Prodi Pendidikan Bahasa Inggris akan pentingnya kebermanfaatan ilmu yang dimiliki oleh para dosen guna pendidikan masyarakat yang lebih baik diluar aktifitas pendidikan di dalam kampus ,2) Bagi Yayasan adalah Kurangnya tenaga pendidik (Bahasa Inggris), yang mana minat santri (Siswa) yang cukup tinggi untuk mampu berbahasa Inggris dan 3) Minimnya bahan ajar yang tersedia di perpustakaan Yayasan Pendidikan dan sosial Roudlotut Thullab.

Kegiatan diharapakan memberikan manfaat bagi kedua pihak. Mereka adalah STKIP Nurul Huda Sukaraja khususnya Prodi Bahasa Inggris sebagai pelaksana kegiatan dan Yayasan Pendidikan dan Sosial Roudlotut Thullab sebagai tempat sasaran.

Bagi STKIP Nurul Huda Sukaraja khususnya prodi Bahasa Inggris dapat meningkatkan dan mengembangkan ilmu pengetahuan sesuai bidangnya kepada masyarakat diluar kampus. Sedangkan bagi Yayasan Pendidikan dan Sosial Roudlotut Thullab dapat meningkatkan kemampuan bahasa Inggris santri dan memunculkan santri yang mampu beradaptasi dengan perkembangan zaman secara global. Sisi lain bagi kedua belah pihak, ini merupakan ajang untuk memepererat tali silaturohim dan kerjasama yang lebih baik kedepanya.

\section{SOLUSI DAN METODE}

Berdasarkan permasalahan tersebut ada beberapa solusi yaitu memberikan bimbingan belajar bahasa inggris dan mengevaluasi diakhir pembelajaran dengan mengadakan English Competition ( Speech Contest \& Quize). Disamping itu untuk membantu meningkatkan belajar santri diberikan beberapa kamus \& buku ajar bahasa Inggris.

Metode pembelajaran dalam kegiatan pengabdian ini adalah pendampingan belajar (ceramah dan praktik). Dimana ceramah diterapkan untuk memberikan penjelasan materi kepada siswa dan praktik di laksanakan setelah siswa mendapatkan arahan dari guru, namun praktik lebih mendominasi dalam kegiatan pembelajaran ini.

\section{HASIL DAN DISKUSI}

Hasil kegiatan pengabdian pada masyarakat mendapatkan sambutan yang positif dari pihak sekolah, terutama karena pelatihan ini sesuai dengan kebutuhan mereka. Motivasi peserta pelatihan 
cukup antusias. Hal ini menandakan adanya keinginan untuk meningkatkan kemampuan mereka dalam penguasaan bahasa Inggris.

\section{PEMBAHASAN}

Pelaksanaan kegiatan pengabdian kepada masyarakat ini sesuai dengan tahapan yaitu:

1. Proses Pembelajaran bimbingan belajar bahasa Inggris yang telah dilakukan selama satu bulan dari tanggal 05 Desember 2018 s/d 05 Januari 2019. Pertemuan dilakukan dua kali dalam seminggu (hari Rabu dan Sabtu). Proses pembelajaran mulai pukul $14.00 \mathrm{~s} / \mathrm{d} 15.30 \mathrm{WIB}$. Peserta kegiatan adalah kelas VII SMP sampai kelas XII SMK Unggulan Roudlotut Thullab.

Dalam pelaksanaannya, tim kegiatan pengabdian yang terdiri dari 3 dosen pendidikan Bahasa Inggris (Eka Agustina, M.Pd., Ainur Rohmah, M.Pd. dan Hastuti Retno K, M.Pd.) melakukan penadampingan belajar Bahasa Inggris selama satu bulan. Pertemuan setiap minggunya dilaksanakan setiap hari Rabu dan Sabtu pada pukul 14.00 WIB - 15.30 WIB. Pendampingan kegiatan ini memberikan materi pembelajaran tentang expression of greeting, Tenses, How do Speech?, dan How to be a good MC. Karna diharapkan dengan kegiatan ini akan ada santri yang bisa menjadi perwakilan sekolah tersebut ketika ada event lomba antar sekolah. Bahkan pihak Pimpinan Yayasan menyampaikan bahwa Yayasan membutuhkan tenaga pendidik untuk Bahasa Inggris mereka.

2. Mengadakan evaluasi akhir pembelajaran dengan kegiatan English Competition. Lomba yang diadakan yaitu Speech Contest dan Quiz. Yang mana diambil juara I, 2 dan 3 untuk masingmasing lomba. Kegiatan ini dilakukan pada saat hari terakhir yaitu hari Jum'at, 04 Januari 2019. Diharapkan para peserta antusias mengikuti lomba ini. Yang mana sebelum pelaksanaan lomba Tim Pengabdian memberikan kesempatan yang sama untuk semua santri yang ingin mengikuti lomba tersebut. Ini dimaksudkan bahwa mereka diberi kesempatan untuk melatih kepercayaan diri untuk menyiapkan mental bersaing dalam sebuah perlombaan untuk menjadi juara.

3. BAKSOS adalah kegiatan penutup yang dilakukan oleh Tim Kegiatan PKM bersama dengan mahasiswa semester tiga sampai tujuh Prodi Pendidikan Bahasa Inggris. Ini dimaksudkan untuk menciptakan rasa ingin berbagi kepada mahasiswa dan terutama dosen itu sendiri. Selain itu untuk memperkuat tali silaturohim antara Yayasan, santri dan STKIP Nurul Huda Sukaraja, terutama Prodi Pendidikan Bahasa Inggris.

Pelaksanaan kegiatan sesuai dengan tahapan adalah sebagai berikut:

Tabel 1

Pelaksanaan Kegiatan

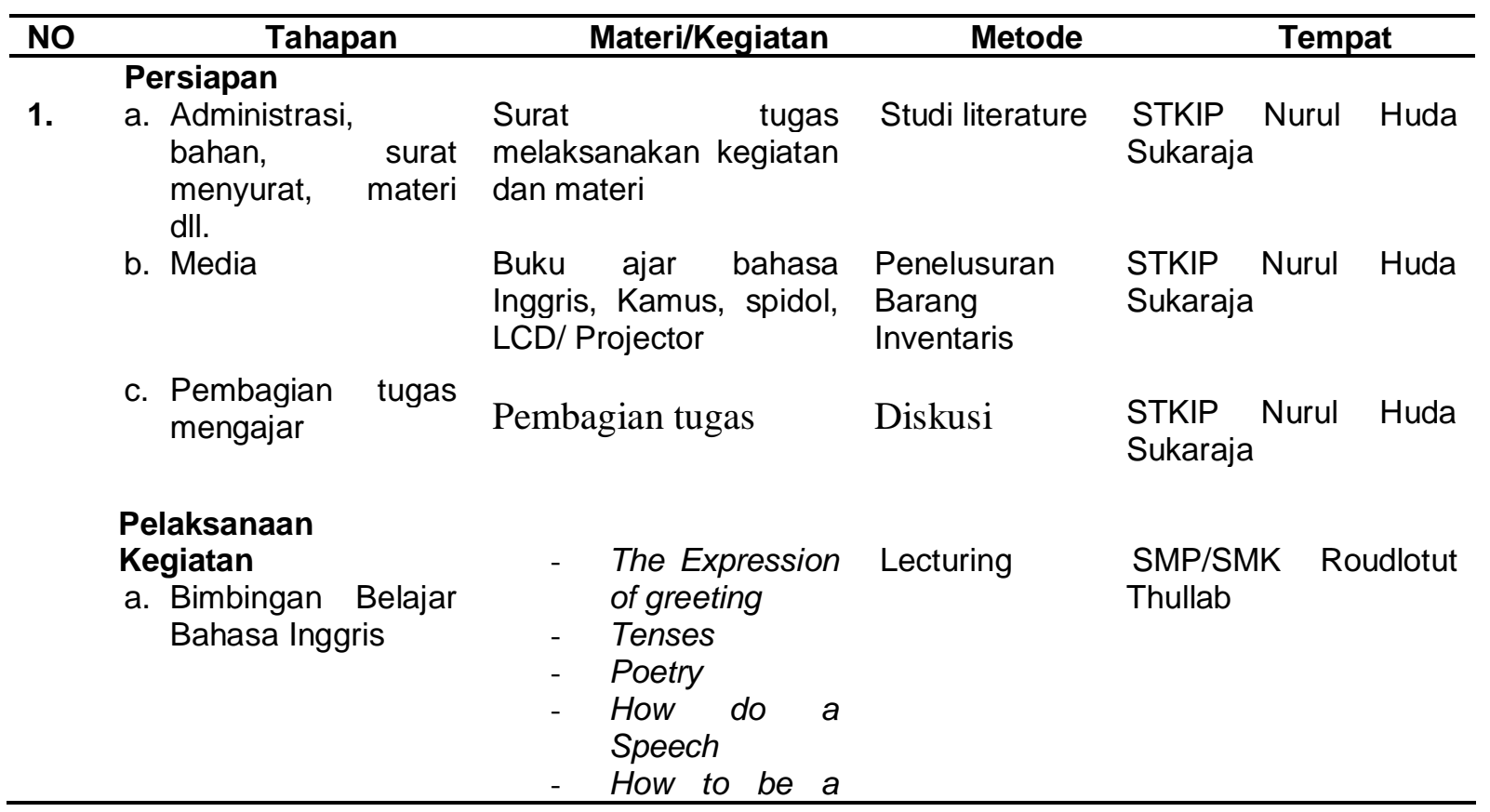


$\operatorname{good} M C$

\begin{tabular}{|c|c|c|c|c|}
\hline b. English Competition & Speech, Quiz & Lomba & SMP/SMK & Roudlotut \\
\hline c. BAKSOS & $\begin{array}{l}\text { Pemberian bantuan } \\
\text { Dana untuk pendidikan } \\
\text { dan buku ajar Bahasa } \\
\text { Inggris }\end{array}$ & $\begin{array}{l}\text { Penyaluran } \\
\text { langsung } \\
\text { dengan pihak } \\
\text { Pimpinan } \\
\text { Yayasan }\end{array}$ & $\begin{array}{l}\text { SMP/SMK } \\
\text { Thullab }\end{array}$ & Roudlotut \\
\hline Penutup & & & $\begin{array}{l}\text { Yayasan } \\
\text { dan Sosial } \\
\text { Thullab }\end{array}$ & $\begin{array}{r}\text { Pendidikan } \\
\text { Roudlotut }\end{array}$ \\
\hline
\end{tabular}

Adapun rincian jadwal pelaksanaan adalah sebagai berikut:

Tabel 2.

Jadwal Pelaksanaan Pendampingan Bimbingan Belajar

\begin{tabular}{|c|c|c|c|c|}
\hline No & HARI/ TANGGAL & WAKTU & MATERI & NARASUMBER \\
\hline \multirow[t]{2}{*}{1} & $05-12-2018$ & $13.00-13.30$ & Pembukaan & Ainur Rohmah \\
\hline & & $13.30-15.00$ & $\begin{array}{l}\text { Pengenalan \& Penyampaian } \\
\text { Materi }\end{array}$ & Eka Agustina \\
\hline 2 & $08-12-2018$ & $14.00-15.30$ & $\begin{array}{l}\text { Expression of greeting, taking - } \\
\text { leaving }\end{array}$ & Hastuti Retno K \\
\hline 3 & $12-12-2018$ & $14.00-15.30$ & $\begin{array}{l}\text { Simple Present Tense } \\
\text { Present Continues Tense } \\
\text { Simple Past Tense }\end{array}$ & Hastuti Retno K \\
\hline 4 & $15-12-2018$ & $14.00-15.30$ & $\begin{array}{l}\text { Simple Future Tense } \\
\text { Simple Perfect Tense }\end{array}$ & Hastuti Retno K \\
\hline 5 & $19-12-2018$ & $14.00-15.30$ & How do Speech? & Eka Agustina \\
\hline 6 & $22-12-2018$ & $14.00-15.30$ & How do Speech? & Eka Agustina \\
\hline 7 & $26-12-2018$ & $14.00-15.30$ & Vocabulary & Ainur Rohmah \\
\hline 8 & $29-12-2018$ & $14.00-15.30$ & Vocabulary & Ainur Rohmah \\
\hline & 02-01-2019 & $14.00-15.30$ & Practice & Eka Agustina \\
\hline \multirow[t]{3}{*}{10} & 05-01-2019 & $08.00-11.00$ & English Competition & Seluruh Tim \\
\hline & & $11.00-12.00$ & BAKSOS & $\begin{array}{l}\text { Tim dan } \\
\text { Mahasiswa }\end{array}$ \\
\hline & & $12.00-12.30$ & Penutup & Tim \\
\hline
\end{tabular}

\section{SIMPULAN}

Adapun kesimpulan dari pengabdian pada masyarakat ini adalah :

1. Kegiatan ini merupakan kegiatan yang baru bagi santri Roudlotut Thullab

2. Para santri merespon positif dengan selalu mengikuti jadwal kegiatan dengan rutin. Selain itu mereka juga sangat antusias mengikuti kegiatan ini meskipun mengalami kesulitan dalam menggunakan bahasa Inggrisnya.

3. Para siswa masih mengalami kesulitan dalam menerapkan teori- teori Speech dan beberapa materi yang diajarkan, diantaranya: kurang percaya diri, masih lemah dalam membaca dan mengucapkan kata atau kalimat bahasa Inggris dengan baik, serta kurangnya berimaginasi dalam berimprovisasi. 
Pendampingan Bimbingan Belajar Bahasa Inggris...

Jurnal Indonesia Mengabdi, 1(1), 2019

\section{UCAPAN TERIMAKASIH}

Ucapan Terima kasih Pengabdian pada Masyarakat ini dibiayai oleh STKIP Nurul Huda Sukaraja, Hibah STKIP Nurul Huda Sukaraja Tahun Anggaran 2018 dengan kontrak nomor : 017/STKIP$\mathrm{NH} / \mathrm{LPPM} / \mathrm{XI} / 2018$.

\section{DAFTAR PUSTAKA}

Ahmadi, A. (2004). Belajar dan Pembelajran. Jakarta: Bumi Aksara

Depdibud. (2002). Kurikulum Berbasis Kompetensi. Panduan Bimbinga dan Konseling Berbasis Kompetensi. Jakarta: Pusat Kurikulum, Depdiknas

Dewi, N.S.R, Mulyani. (2012) Pengembangan Media Bimbingan Belajar Berbasis Komputer Tentang Strategi Mengatasi Stres Dalam Belajar Untuk Siswa Kelas XI di MAN 3 Yogyakarta. Tersedia di http://eprints.uny.ac.id/9570/2/bab\%202\%20NIM.\%2008104241024.pdf. (online).

Hamalik, O. (2002). Psikologi belajar mengajar. Bandung: Sinar Baru Algensindo. 